\title{
MOTOR ACTIVITY AS THE BASIS OF A HEALTHY LIFESTYLE OF STUDENT YOUTH
}

DOI: 10.36740/WLek202006123

\author{
Grygoriy P. Gribann ${ }^{1}$, Tetiana Ye. Yavorska ${ }^{2}$, Pavlo P. Tkachenko ${ }^{3}$, Olga V. Kuvaldina ${ }^{4}$, Zoia M. Dikhtiarenko ${ }^{5}$, \\ Eduard A. Yeromenko ${ }^{5}$, Andrii M. Lytvynenko ${ }^{6}$, Nataliia V. Hresa ${ }^{7}$, Ivan M. Okhrimenko ${ }^{8}$, Igor S. Ovcharuk9, \\ Kostiantyn V. Prontenko ${ }^{10}$ \\ 1 DEPARTMENT OF PHYSICAL EDUCATION AND SPORT IMPROVEMENT, ZHYTOMYR IVAN FRANKO STATE UNIVERSITY, ZHYTOMYR, UKRAINE \\ 2DEPARTMENT OF THEORETICAL AND METHODICAL BASIS OF PHYSICAL EDUCATION AND SPORT, ZHYTOMYR IVAN FRANKO STATE UNIVERSITY, \\ ZHYTOMYR, UKRAINE \\ ${ }^{3}$ DEPARTMENT OF PHYSICAL EDUCATION, ZHYTOMYR NATIONAL AGROECOLOGICAL UNIVERSITY, ZHYTOMYR, UKRAINE \\ ${ }^{4}$ DEPARTMENT OF THEORETICAL FOUNDATIONS OF OLYMPIC AND PROFESSIONAL SPORTS, ADMIRAL MAKAROV NATIONAL UNIVERSITY \\ OF SHIPBUILDING, MYKOLAIV, UKRAINE \\ ${ }^{5}$ DEPARTMENT OF HORTING AND REHABILITATION, UNIVERSITY OF STATE FISCAL SERVICE OF UKRAINE, IRPIN, UKRAINE \\ ${ }^{6}$ DEPARTMENT OF PHYSICAL EDUCATION, KHARKIV NATIONAL UNIVERSITY OF RADIO ELECTRONICS, KHARKIV, UKRAINE \\ ${ }^{7}$ DEPARTMENT OF SOCIOLOGY AND PSYCHOLOGY, KHARKIV NATIONAL UNIVERSITY OF INTERNAL AFFAIRS, KHARKIV, UKRAINE \\ ${ }^{8}$ DEPARTMENT OF LEGAL PSYCHOLOGY, NATIONAL ACADEMY OF INTERNAL AFFAIRS, KYIV, UKRAINE \\ ${ }^{9}$ DEPARTMENT OF PHYSICAL EDUCATION, SPECIAL PHYSICAL TRAINING AND SPORT, ODESA MILITARY ACADEMY, ODESA, UKRAINE \\ ${ }^{10}$ DEPARTMENT OF PHYSICAL EDUCATION, SPECIAL PHYSICAL TRAINING AND SPORT, S. P. KOROLIOV ZHYTOMYR MILITARY INSTITUTE, ZHYTOMYR, \\ UKRAINE
}

\begin{abstract}
The aim is to find out the role of motor activity in developing a healthy lifestyle of student youth in the process of physical education.

Materials and methods: The study involved 647 students, aged 18-22. The research methods are the analysis and synthesis of the literature, analysis of curricula, programs, methodological support and quality of training, questionnaires, and the methods of mathematical statistics.

Results: It is determined that the majority of the students had no need for a healthy lifestyle, the lack of knowledge in this area, low activity while performing the requirements of a healthy lifestyle, irrational organization of educational activities, bad habits and other factors that negatively affect their health.

Conclusions: The current system of physical education in the higher education institutions of Ukraine cannot change the attitude of students to a healthy lifestyle. The purpose of physical education, in addition to the formation of physical skills and development of students' physical qualities, should be educational work aimed at forming a positive attitude towards a healthy lifestyle.
\end{abstract}

KEY WORDS: motor activity, healthy lifestyle, health, physical education, student

Wiad Lek. 2020;73(6):1199-1206

\section{INTRODUCTION}

One of the necessary conditions of life and the main form of human behavior in the external environment is motor activity. It improves working capacity, health, provides diverse harmonious development, the functioning of the cardiovascular, respiratory, hormonal and other systems of the body, activates the neuromuscular system and the mechanisms of the reflexes transmission from muscles to internal organs $[1,2,3,4]$. At the same time, a low level of outlook and motivation in the field of health, wellness physical culture, and healthy lifestyle negatively affects the process of motor activity of students that consequently worsens their health, the level of physical development, physical fitness and increases the number of diseases $[5,6$,
$7,8,9]$. Therefore, the original methodology of introducing health-saving technologies into the activities of higher education institutions should be responsible for the health of students, their level of biological and social adaptability, ensure the individuality and conformity of the activities of teachers and medical staff of an institution. The Departments of Physical Education have the task of preserving and improving the health of students, transforming the way of life typical for a large part of students into a healthy one that would not destroy but improve their health.

The analysis of recent studies and publications [10, 11, $12,13]$ showed that motor activity is an integral part of the lifestyle and behavior of a person, which is determined by socioeconomic and cultural factors, and which depends on 
the organization of physical education, morphofunctional characteristics of the body, the type of nervous system, the amount of free time, the motivation for classes, the availability of sports facilities and rest areas. By the motor activity of a person, it is meant any movement of the body made by skeletal muscles that result in an increase in energy consumption that is higher than the main metabolism [14].

Motor activity is conditioned by three factors, including biological, social and personal $[6,15]$. The amount of motor activity of students and the needs of their organisms also depend on the age, gender, the type of constitution, morphofunctional capabilities, the type of nervous system, heredity, the level of physical fitness, motivation for classes, lifestyle, geographical and climatic conditions, the amount of free time and the character of its use, etc. $[16,17]$.

The sports traditions, education system, the place and role of physical education and sports in this system, the availability of modern programs of physical education and their implementation by qualified teachers play an important role in the formation of physical activity $[18,19]$. The limitation of motor activity of students reduces the efficiency of the body's defense mechanisms to adverse environmental influences, develops a tendency for various diseases [20]. Systematic exercises and sports help an organism to reach a new, higher level of development [21,22]. Intensive sports activities also form adaptive transformations in the body that cannot be achieved by the usual dosed physical training and physical work. Dosing motor activity (combined into a specific system of physical activity) has a medical, preventive, health-improving effect and training effect on students who have health disorders $[23,24]$.

\section{THE AIM}

The aim of the study is to find out the role of motor activity in forming a healthy lifestyle of student youth in the process of physical education.

The objectives:

1) according to the results of the researches of various scientists, to characterize the concept of a healthy lifestyle;

2) to investigate the attitude of students to physical activity in the process of physical education as a basis for forming a healthy lifestyle.

\section{MATERIALS AND METHODS}

The organization and performance of theoretical and experimental studies, the analysis and interpretation of results, the formulation of conclusions were carried out in 2011-2018 and included four stages. The study involved 647 students, aged 18-22.

In the first stage, it was examined the state of the problem of the study, determined the experimental base and research program, conducted the analysis of literary sources on healthy lifestyles and the questionnaire. On the basis of systematization and generalization of literary sources and other data, a program of engaging students in a healthy lifestyle in the process of physical education was formed, and the main factors that characterize students' health, their attitude to physical activity were determined. In the second and third stages, new sections of the questionnaire and comparative analysis were conducted. The questionnaire revealed the motivational desires and physical and sports interests of the students in various types of physical activity. In the fourth generalizing stage of the study (2018), the final analysis and interpretation of the data were conducted.

The state of students' motor activity was evaluated according to the weekly time budget questionnaire developed by the authors. The self-assessment of physical activity and attitude of students to physical education were also estimated by the original questionnaire. The evaluation of diseases and their consequences was conducted with the help of medical records and certificates.

The research methods included theoretical (the analysis and synthesis of literary sources; analysis of curricula, programs, methodological support and quality of training), and empirical (questioning, pedagogical observations, methods of mathematical statistics).

This study complies with the ethical standards of the Act of Ukraine "On Higher Education" No.1556-VII dated 01.07.2014 and the Letter from the Ministry of Education and Science of Ukraine "On the Academic Plagiarism Prevention" No. 1/11-8681 dated 15.08.2018. Also, this study followed the regulations of the World Medical Association Declaration of Helsinki - ethical principles for medical research involving human subjects. Informed consent was received from all individuals who took part in this research.

\section{RESULTS}

The dramatic negative tendencies in the health status of student youth in Ukraine are related, first of all, to the restriction of physical activity, significant disorders of the nutrition system (inadequate, poor nutrition, low-quality food, malnutrition, over nutrition, the lack of regime, etc.), bad habits (smoking, alcohol and drug abuse, etc.), mental overwork and stress, environmental pollution and poor sanitary and living conditions, etc. $[10,17,22]$. The fastest, most affordable and easiest way to solve this problem in Ukraine is to change students' attitudes toward a healthy lifestyle.

The problem of healthy lifestyle formation is largely related to the level of the students' and teachers' culture. It is determined that more successfully the students' need for physical self-improvement is formed, the higher the educational level and the degree of development of other needs are, and that is, the more their personality is formed. A direct correlation between the formation of the need for physical self-improvement and the professional orientation of the students' personality was found that confirms the dialectical unity of physical and intellectual activity [25].

A healthy lifestyle should be considered the forms and methods of daily human activity that contribute to improving the reserve capacity of the organism, the successful fulfillment of social and professional functions, the 
Table I. The students' weekly time expenditure on exercise and sports ( $n=647$, hours and min).

\begin{tabular}{|c|c|c|c|c|c|c|}
\hline \multirow{3}{*}{ Types of activities } & \multicolumn{6}{|c|}{ Studying departments } \\
\hline & \multicolumn{2}{|c|}{ Special } & \multicolumn{2}{|c|}{ Main } & \multicolumn{2}{|c|}{ Sports } \\
\hline & time & $\%$ & time & $\%$ & time & $\%$ \\
\hline Educational classes & 4:00 & 2.4 & 4:00 & 2.4 & - & - \\
\hline Morning exercises & $1: 57$ & 1.2 & $1: 33$ & 0.9 & 2:03 & 1.2 \\
\hline Extracurricular activities & $1: 23$ & 0.8 & $2: 27$ & 1.5 & 9:34 & 5.7 \\
\hline Competitions and sports events & - & - & $0: 13$ & 0.1 & $1: 04$ & 0.6 \\
\hline Totally & $7: 20$ & 4.4 & $8: 13$ & 4.9 & $12: 41$ & 7.5 \\
\hline
\end{tabular}

Table II. The students' level of satisfaction with their motor activity ( $\mathrm{n}=647, \%)$.

\begin{tabular}{|c|c|c|c|c|c|}
\hline \multirow{2}{*}{$\begin{array}{l}\text { The year } \\
\text { of study }\end{array}$} & \multirow[b]{2}{*}{ Gender } & \multicolumn{4}{|c|}{ Subjective evaluation } \\
\hline & & $\begin{array}{l}\text { Satisfied } \\
\text { completely }\end{array}$ & $\begin{array}{l}\text { Almost } \\
\text { satisfied }\end{array}$ & $\begin{array}{l}\text { Satisfied } \\
\text { partially }\end{array}$ & $\begin{array}{c}\text { Not } \\
\text { satisfied }\end{array}$ \\
\hline \multirow{2}{*}{$1 \mathrm{st}$} & male & 41.9 & 37.1 & 19.1 & 1.9 \\
\hline & female & 20.7 & 30.5 & 42.7 & 6.1 \\
\hline \multirow{2}{*}{ 2nd } & male & 35.9 & 45.4 & 15.6 & 3.1 \\
\hline & female & 27.7 & 41.4 & 23.6 & 7.3 \\
\hline \multirow{2}{*}{$3 r d$} & male & 25.7 & 28.6 & 40.0 & 5.7 \\
\hline & female & 17.6 & 35.3 & 39.3 & 7.8 \\
\hline \multirow{2}{*}{ 4th } & male & 32.4 & 32.4 & 26.5 & 8.7 \\
\hline & female & 22.4 & 42.3 & 31.8 & 3.5 \\
\hline \multirow{3}{*}{ Totally } & male & 36.6 & 37.3 & 22.3 & 3.8 \\
\hline & female & 23.9 & 38.6 & 31.1 & 6.4 \\
\hline & totally & 28.6 & 38.2 & 27.8 & 5.4 \\
\hline
\end{tabular}

prevention of the most common diseases [2]. There are different interpretations of the concept of a healthy lifestyle, but their essence is to preserve and improve health. E. N. Vayner [26] considers a healthy lifestyle to be the one which corresponds to the genetically determined typological characteristics of a given person, the specific conditions of one's life, aimed at the formation, preservation, and improvement of health and the complete fulfillment of the socio-biological functions. According to the author, a healthy lifestyle is the most efficient way and method of promoting health. M. M. Bulatova and Yu. O. Usachov [27] interpret a healthy lifestyle as activities aimed at the formation, preservation, improvement, and recovery of health, as conditions and prerequisites for the realization and development of other parties and aspects of a lifestyle. G. Apanasenko and L. Dolzhenko [28] define a healthy lifestyle as a set of wellness activities that contribute to the preservation and improvement of human health. This definition reveals a healthy lifestyle through the concept of the complex of wellness activities. The activities are selected depending on the components that are the parts of a healthy lifestyle. Among the most important elements that give a modern interpretation of a healthy lifestyle $\mathrm{T}$. Yu. Krutsevych [29] distinguished: 1) rational individual lifestyle that promotes health (mental activity, healthy nutrition, proper spiritual regime, personal hygiene, refusal of smoking and alcohol abuse); 2) active participation in the formation of social relations that contribute to the preservation and development of an individual; 3) hygienic rational behavior, taking into account the requirements of the environment; 4) conscious participation in the organization of working conditions that contribute to the maintenance of health and increase in working capacity; 5) a reasonable attitude to health care measures in disease. Among the components of a healthy lifestyle, R. S. Paffenbarger and E. Olsen [30] distinguish regular three meals a day, daily breakfast, regular motor activity of medium intensity, good quality sleep (7-8 hours), refusal of smoking, maintenance of optimal body weight, non-consumption or restricted use of alcohol. The additional use of vitamins A, $\mathrm{C}, \mathrm{E}$, and beta-carotene, reducing stress and engaging in community service are also added to these components. Other experts E. T. Howley and D. B. Franks [31] believe that the purpose of a healthy lifestyle is to create a basis for positive health with minimal risk of its disorders, characterized by favorable hereditary indicators, the level of serum cholesterol, the level of blood pressure, normal body weight, the condition of the cardiorespiratory system, the mobility of the spine, the strength and endurance of the muscles, the ability to overcome stress. These authors also include the following components to a healthy lifestyle: good heredity; health-promoting habits; habits that promote personal safety; environmentally friendly conditions; preventive measures; good physical condition; regular motor activity; proper nutrition. Among the factors that influence a healthy lifestyle, scientists distinguish adiposity, osteochondrosis, depression $[6,32]$. In this regard, psycho-pedagogical and specialized literature is actively 
discussing the definition and justification of the lifestyle that would improve the health of students.

Therefore, a healthy lifestyle can be interpreted as the behavior of a person who reflects a certain life position aimed at maintaining and promoting health based on compliance with the rules and requirements of personal and social hygiene. In general, the analysis of literary sources gives grounds to state that the main factor of a healthy lifestyle is, first of all, motor activity, which requires the student to achieve some success in this field, get rid of bad habits, stick to healthy eating, acclimation, controlling one's own weight [33].

The increase in students' physical activity is one of the main factors of a healthy lifestyle and means of health improvement. It is revealed that on average $5.9 \%$ of the total time is spent on physical education classes, sports training, participation in sports competitions and various sports activities, independent physical exercises and hygienic morning exercises. It can be certainly noted that this time is not enough to provide physical activity, mental recovery processes. There were no special changes in the structure of students' time budget during years of study. Many higher education institutions have eliminated physical education classes for senior students or substantially reduced the number of hours that negatively affects students' general motor activity.

The analysis of the time budget, according to studying departments, revealed even more significant contrasts in spending time on exercise and sports (Table I). The students of special and main educational departments spend even less time on the physical exercises and sport than generally at the university (respectively, 7 hours $20 \mathrm{~min}-4.4 \%$ and 8 hours $13 \mathrm{~min}-4.9 \%)$. At the same time, the indicator of the students of the sports department is significantly higher (12 hours $41 \mathrm{~min}-7.5 \%$ ). The structure of the students' of the sports department free time is more refined and the time is used more rationally. Despite the considerable time spent on sports, they pay more attention to social activities, spend less time on passive rest, and follow regimes of study, daily routine and rest more clearly.

The high level of physical activity of students favorably influences the development of physical qualities, the level of physical fitness and health and ensures the successful fulfillment of program requirements and tests. It is determined that only $36.6 \%$ males and $23.9 \%$ females among students are satisfied with their physical activity while studying in higher education institutions. The male students of the first year of study $-41.9 \%$ are defined to be satisfied with their motor activity the most, that is caused by a better material and technical equipment of the sports base, teaching and coaching staff, performing sports and mass work in higher educational establishments, in comparison to schools. In the second or third year, the level of satisfaction with motor activity is decreased. In contrast, the female students of the first year of study have a low level of satisfaction with their motor activity and it remains practically the same throughout the study period (Table II). In the special education department, only $20.8 \%$ male students are satisfied with their motor activity, in the main department $-38.9 \%$, and in the sports one $-45.8 \%$. The significantly lower rates were obtained from female students: $18.6 \%$ in the special department, $23.1 \%$ in the main and $35.4 \%$ in the sports departments.

Accordingly, the deficit of motor activity leads to a deterioration of health and the development of a number of diseases. Diseases are significantly reflected in the decrease in students' motor activity and its complete loss. During the year, 645 students lost 10478 person-days because of illness that is $4.45 \%$ of the total number of days.

The analysis of the causes of students' labor capacity loss showed significant differences not only in the number of diseases but also in their consequences between men and women. Among the students who lost their capacity for work during the year, there were $2.18 \%$ males and $6.19 \%$ females of the first year of study, 2.69 and $4.48 \%$ respectively of the second year. The situation was even more vulnerable in the third and fourth years. The male students' loss of capacity for work had a decreasing tendency, and the female students', on the contrary, had a significantly decreasing tendency. It was also revealed the difference in labor capacity loss between the students of different educational departments. Acute respiratory diseases are dominant in all educational departments, especially for females. The students of the special education department have the highest rate of labor capacity loss $-6.29 \%(2.71 \%$ - males, $7.99 \%$ - females), the next place is going to the students of the sports educational department $-4.3 \%$ $(2.02 \%$ - males, $6.57 \%$ - females), the students of the main education department have the best indicators.

One of the tasks of physical education is the correct formation of value orientations, the realization by students of the most important needs in this field of activity. Only under such a condition, it is possible to form a value-based attitude towards a healthy lifestyle. However, the system of physical education in higher education institutions could not form the correct attitude to exercise of the half of students formed a negative attitude to the process of physical education and physical activity (Table III).

The criterion of the efficiency and quality of the process of physical education is the students' upbringing, that is, the high spiritual and moral-volitional qualities, which are based on an internal desire to systematically maintain the health, a sufficient level of physical fitness and development, love for physical culture and sports and in general a healthy lifestyle.

There are a number of factors that encourage students to exercise, but they lose their strength when students face some difficulties and obstacles quite often. The main factors contributing to the positive attitude of students to physical education are responsibility and discipline, taking pleasure from the lessons, the example of a teacher, friends, etc. (Table IV).

The efficiency of physical exercises is significantly influenced by the form of classes offered to students. The students give the greatest preference to the classes in the sports training department and sections (35.2\%) and give considerable attention (30.7\%) to independent classes with a group of friends. The male students are particularly 
Table III. The aim of attending physical education classes by the students of different educational departments $(n=647, \%)$.

\begin{tabular}{|c|c|c|c|c|}
\hline \multirow{2}{*}{ The aim } & \multirow{2}{*}{ Gender } & \multicolumn{3}{|c|}{ Studying departments } \\
\hline & & Special & Main & Sports \\
\hline \multirow{2}{*}{ The health improvement } & male & 26.4 & 36.5 & 55.9 \\
\hline & female & 31.9 & 38.0 & 46.1 \\
\hline \multirow{2}{*}{ The increase in physical performance } & male & 28.3 & 51.6 & 42.3 \\
\hline & female & 27.8 & 30.3 & 35.3 \\
\hline \multirow{2}{*}{ The desire to be attractive } & male & 7.5 & 11.9 & 16.9 \\
\hline & female & 22.7 & 21.4 & 30.7 \\
\hline \multirow{2}{*}{ The improvement of sports results } & male & 7.5 & 11.1 & 23.7 \\
\hline & female & 4.1 & 9.7 & 23.0 \\
\hline \multirow{2}{*}{ Taking pleasure } & male & 3.8 & 5.5 & 22.0 \\
\hline & female & 4.1 & 3.2 & 18.5 \\
\hline \multirow{2}{*}{ To pass an exam } & male & 41.5 & 34.1 & 20.3 \\
\hline & female & 49.4 & 42.9 & 18.5 \\
\hline \multirow{2}{*}{ The fear of being punished } & male & 11.3 & 6.3 & 1.7 \\
\hline & female & 3.0 & 4.4 & 4.6 \\
\hline
\end{tabular}

Table IV. The factors contributing to the positive attitude of the students of different educational departments to the process of physical education ( $\mathrm{n}=647, \%$ ).

\begin{tabular}{|c|c|c|c|c|}
\hline \multirow{2}{*}{ The factors } & \multirow{2}{*}{ Gender } & \multicolumn{3}{|c|}{ Studying departments } \\
\hline & & Special & Main & Sports \\
\hline \multirow{2}{*}{ Responsibility and discipline } & male & 32.1 & 42.8 & 40.6 \\
\hline & female & 28.7 & 21.8 & 35.4 \\
\hline \multirow{2}{*}{$\begin{array}{l}\text { Harmony of spiritual and physical } \\
\text { development }\end{array}$} & male & 20.7 & 17.4 & 20.3 \\
\hline & female & 16.4 & 15.8 & 13.8 \\
\hline \multirow{2}{*}{ Physical education teacher } & male & 28.3 & 10.3 & 11.9 \\
\hline & female & 22.6 & 29.5 & 18.5 \\
\hline \multirow{2}{*}{ Friends } & male & 17.0 & 10.3 & 15.3 \\
\hline & female & 11.3 & 8.5 & 10.8 \\
\hline \multirow{2}{*}{$\begin{array}{l}\text { The availability and accessibility of sports } \\
\text { facilities }\end{array}$} & male & 17.0 & 18.2 & 11.9 \\
\hline & female & 7.2 & 8.1 & 9.2 \\
\hline \multirow{2}{*}{$\begin{array}{l}\text { The control of the dean's office and } \\
\text { department of physical education }\end{array}$} & male & 24.5 & 6.3 & 6.8 \\
\hline & female & 21.6 & 20.2 & 7.7 \\
\hline \multirow{2}{*}{ Parents } & male & 7.5 & 3.1 & 3.4 \\
\hline & female & 2.1 & 2.0 & 6.2 \\
\hline
\end{tabular}

Table V. The classes in physical education which the students prefer $(n=647, \%)$

\begin{tabular}{|c|c|c|c|c|c|c|}
\hline \multirow{2}{*}{ The educational classes } & \multirow{2}{*}{ Gender } & \multicolumn{4}{|c|}{ The year of studying } & \multirow{2}{*}{ Total } \\
\hline & & $1 \mathrm{st}$ & 2nd & 3rd & 4th & \\
\hline \multirow{2}{*}{ With music } & male & 37.1 & 32.8 & 17.1 & 17.6 & 30.2 \\
\hline & female & 56.1 & 50.8 & 58.8 & 63.5 & 55.5 \\
\hline \multirow{2}{*}{ With gym machines } & male & 25.7 & 23.4 & 31.4 & 11.8 & 28.1 \\
\hline & female & 20.7 & 57.1 & 52.9 & 28.2 & 43.2 \\
\hline \multirow{2}{*}{ Using sports games } & male & 23.8 & 34.4 & 57.1 & 55.9 & 36.1 \\
\hline & female & 18.3 & 12.0 & 11.8 & 14.1 & 13.7 \\
\hline \multirow{2}{*}{ At the stadium } & male & 23.8 & 20.3 & 17.1 & 20.6 & 21.4 \\
\hline & female & 23.2 & 3.7 & 5.9 & 5.9 & 8.3 \\
\hline \multirow{2}{*}{ In the park, in the open air } & male & 11.4 & 12.5 & 20.0 & 8.8 & 12.6 \\
\hline & female & 13.4 & 12.0 & 11.8 & 4.7 & 10.8 \\
\hline
\end{tabular}

interested in mini-football, football, volleyball, basketball, table tennis, oriental martial arts, kettlebell lifting, boxing and training with gym machines, and female students prefer aerobics, shaping, rhythmic gymnastics, training with gym machines, and a small part of female students prefer sports games. 
The quality and efficiency of the physical education process depend to a large extent on the content of the training classes, their location, the emotional climate in classes and the choice of the means of development of physical qualities. The students enjoy the classes with functional music the most (Table V). The students, especially females, are quite fond of training with gym machines, while males prefer sports games. The students are less keen on athletics, and cross-country run held at the stadium and in the open air.

One of the main goals of exercise should be related to students' belief that it has great value for their lives. It is important for students to constantly enjoy such classes and feel muscular pleasure.

It is necessary to build the educational process so that it promotes the development of the ability to see not temporary but long-lasting values of life, to experience a certain achievement, to enjoy the classes, get positive emotions.

\section{DISCUSSION}

The studies conducted showed that the majority of students have no need for a healthy lifestyle, the lack of knowledge in this area, low activity while performing the requirements of a healthy lifestyle, irrational organization of educational activities, bad personal hygiene, bad habits and other factors that negatively affect their health. The solution to this problem is largely based on the attitude of each student to one's own health, the desire to be healthy and to be able to preserve and maintain health throughout the active social life through self-organization. Therefore, the attitude to the health problem in a particular group should be fundamentally changed by students and teachers, and also by the family, civic and sports organizations, health services and departments, etc.

The current system of physical education can not fully solve the problems that would change the students' attitudes toward a healthy lifestyle. The purpose of physical education, in addition to the formation of motor skills, abilities, and physical qualities, should be a great educational work. The purpose of such educational work should be directed not only to the period of study in a higher education institution but firstly, to the students' further life and it should promote the formation of fitness and health competences. This role falls on the promotion of a healthy lifestyle, that is a purposeful activity aimed at spreading and promotion of health and fitness knowledge.

The formation of the attitude focused on a healthy lifestyle and following it both in higher education and in later life should start with:

- the assessment of the knowledge and skills in a healthy lifestyle;

- the assessment of health, bad habits, diseases and disorders of the musculoskeletal system and the ways to eliminate them;

- the awareness of the need to maintain a healthy lifestyle, showing interest in the specific types of its expression by each student;
- the assessment of students' activity while performing the requirements of a healthy lifestyle, taking physical and health measures;

- the formation of the students' positive attitude to the means of physical culture and sports and the subject of Physical Education;

- the formation of a psychological attitude for the future regarding maintaining high motor activity, negative attitude to bad habits, etc.;

- the determination of the types of physical activity that suit the student's individual abilities and temperament the most;

- the formation of the confidence that the time spent exercising is offset by good health;

- goal setting and following it, regardless of the exhaustion, the lack of time, bad weather, etc.;

- the availability of different variants of individual fitness programs.

\section{CONCLUSIONS}

1. The formation of a healthy lifestyle of students has many different interpretations and recommendations. This indicates that there is no single way to maintain a healthy lifestyle and an active life. Therefore, the intensification of pedagogical health-saving technologies requires the conscious involvement of the potential of each student and the efficient adaptation to educational activities.

2. Ensuring optimal motor activity of student youth is one of the priority factors of a healthy lifestyle and means of wellness. The standard of the motor activity of students of higher education institutions can be considered such a value that fully satisfies the biological needs for movement, meets the functional capabilities of the organism, promotes its development, physical fitness, health preservation, the improvement of working capacity and ensures the successful fulfillment of the duties. In the scientific literature and programs on physical education, the optimal amount of the physical activity of students is 12-14 hours a week with sufficient physiological activity.

The prospects for further research are aimed at the development of innovative health and fitness technologies for the formation of a healthy lifestyle of student youth.

\section{REFERENCES}

1. Gruzieva T., Galiienko L., Pelo I. et al. Health and lifestyle of students' youth: status, problems and ways of solution. Wiad Lek. 2018;71(9):1753-1758.

2. Futornyj S. M. Dvyghateljnaja aktyvnostj y ee vlyjanye na zdorovj'e y prodolzhyteljnostj zhyzny cheloveka [Motor activity and its effect on human health and longevity]. Fyzycheskoe vospytanye studentov. 2011;4:79-84. (In Russian).

3. Bulatova M. M. Fitnes i dvigatel'naya aktivnost': problemy i puti resheniya [Fitness and physical activity: problems and solutions]. Teoriya i metodika fizichnogo vikhovannya i sportu. 2007;1:3-7. (In Russian).

4. Balsevich V. K. Fizicheskaya aktivnost cheloveka [Human physical activity]. Kyiv, 1987. 224 p. (In Russian). 
5. Bolotin A., BakayevV. Structure and content of the educational technology of managing students'healthy lifestyle. Journal of Physical Education and Sport. 2015; 15(3): 362-364. doi:10.7752/jpes.2015.03054.

6. Muntjan V. S. Analyz faktorov, opredeljajushhykh zdorovj'e cheloveka y okazyvajushhykh na negho vlyjanyja [Analysis of factors that determine human health and influence it]. Fyzycheskoe vospytanye studentov. 2010; 6: 44-47. (In Russian).

7. Mozolev 0., Bloshchynsky l., Alieksieiev 0. et al. Influence of modern fitness technologies on the state of health and development of motor abilities of 17-19-year-old female students. Journal of Physical Education and Sport. 2019; 19(Supplement issue 3): 917-924. doi:10.7752/jpes.2019.s3132.

8. Prysiazhniuk S., Tolubko V., Oleniev D. et al. The influence of physical activities on biological age parameters of the first-year female students from the special medical department. Journal of Physical Education and Sport. 2018;18(2):561-564. doi:10.7752/jpes.2018.02081.

9. Kharchenko 0., Kharchenko N., Shaparenko I. et al. Analysis of the physical development of youth and the state of its health. Wiad Lek. 2019;72(4): 575-578.

10. Mozolev 0., Halus 0., Bloshchynskyi I. et al. Human resources management of educational development in sphere of physical culture and sports in Ukraine: comparative analysis (1992-2016). Journal of Physical Education and Sport. 2019; 19(Supplementissue 1): 185-192. doi:10.7752/jpes.2019.s1028.

11. Prontenko K., Griban G., Prontenko V. et al. Health improvement of cadets from higher military educational institutions during kettlebell lifting activities. Journal of Physical Education and Sport. 2018;18(1): 298-303. doi:10.7752/jpes.2018.01040.

12. Rus C. M. Physical education and sports - a field more valuable and actual than ever. Editorial. Revista Romaneasca pentru Educatie Multidimensionala. 2017;9(3):7-9. doi:https://doi.org/10.18662/ rrem/2017.0903.01.

13. Zavydivska 0., Zavydivska N., Khanikiants 0 . Self-management as a condition for creating a health culture among students. Journal of Physical Education and Sport. 2016; 16(1):592-597. doi:10.7752/ jpes.2016.s1093.

14. Griban G. P. Zhyttiediialnist ta rukhova aktyvnist studentiv [Life activity and mobility of students]. Zhytomyr: Ruta; 2009, 594 p. (In Ukrainian).

15. Prontenko K., Griban G., Dovgan N., et al. Students' health and its interrelation with physical fitness level. Sport Mont. 2019;17(3): 41-46. doi 10.26773/smj.191018.

16. Zelenskyi B., Zelenskyi R. Motivation: attitude of students of higher education institutions of the I-II accreditation levels toward physical education classes. Theory and Methods of Physical Education. 2018;18(3); 114-125. doi:10.17309/tmfv.2018.3.02.

17. Budagh'janc Gh. M. Zdorovyj sposib zhyttja - osnovna umova profilaktyky deviantnoji povedinky pidlitka (istorychnyj aspekt) [Healthy lifestyle - the main condition for the prevention of adolescent deviant behavior (historical aspect)]. Pedaghoghika, psykhologhija ta medykobiologhichni problemy fizychnogho vykhovannja i sportu. 2010; 6: 25-28. (In Ukrainian).

18. Cucui A. I. Study on sports activities in the free time of gymnasium cycle students. Revista Romaneasca pentru Educatie Multidimensionala. 2018;10(4):82-91. doi:https://doi.org/10.18662/rrem/74.

19. Prontenko K., Bloshchynskyi I., Griban, G. et al. Formation of readiness of future physical culture teachers for professional activity. Universal Journal of Educational Research. 2019;7(9):1860-1868. doi: 10.13189/ ujer.2019.070903.
20. Warburton D., Nicol C. W., Bredin S. S. D. Health benefits of physical activity: the evidence. Canadian Medical Association Journal. 2006;174:801-809.

21. Bulych E. Gh., Muravov Y. V. Zdorovje cheloveka: Byologhycheskaja osnova zhyznedejateljnosty y dvyghateljnaja aktyvnostj v ee stymuljacyy [Human health: the biological basis of vital activity and motor activity in its stimulation]. Kyiv: Olympic Literature; 2002, 424 p. (In Russian).

22. World Health Organization. Global recommendations on physical activity for health. 2015. Available from: http://www.who.int/ dietphysicalactivity/factsheet_recommendations.

23. Leuciuc F. Perception on physical education among students. Revista Romaneasca pentru Educatie Multidimensionala. 2018;10(2):134-143. doi:https://doi.org/10.18662/rrem/51.

24. Griban G., Prontenko K., Zhamardiy V. et al. Professional stages of a physical education teacher as determined using fitness technologies. Journal of Physical Education and Sport. 2018;18(2):565-569. doi:10.7752/jpes.2018.02082.

25. Griban G. P.Vpliv fizichnih vprav na rozumovu ta intelektualnu diyalnist studentiv [The influence of exercise on the mental and intellectual activity of students]. Zhytomyr: Ruta; 2008, 122 p. (In Ukrainian).

26. Vayner E. N. Valeologiya [Valeology]. Moskow: “Flinta", "Nauka”; 2001, 416 p. (In Ukrainian).

27. Bulatova M. M., Usachov Yu. O. Suchasni fitnes-ozdorovchi tekhnologhiji u fizychnomu vykhovanni. Teorija ta metodyka fizychnogho vykhovannja [Modern fitness-health-improving technologies in physical education. Theory and methods of physical education]. Kyiv: Olympic Literature; 2008, 320 p. (In Ukrainian).

28. Apanasenko G., Dolzhenko L. Rivenj zdorov'ja i fiziologhichni rezervy orghanizmu. [The level of health and physiological reserves of the organism]. Teorija i metodyka fizychnogho vykhovannja i sportu. 2007;1:17-21. (In Ukrainian).

29. Krutsevych T. Yu. Teoriia i metodyka fizychnoho vykhovannia [Theory and methods of physical education]: pidruchnyk dlia stud. vuziv fiz. vykhov. isportu. T. 1. Zahalni osnovy teorii i metodyky fizychnoho vykhovannia. Kyiv: Olympic Literature; 2008, 391 p. (In Ukrainian).

30. Paffenbarger R. S., Olsen E. Zdorovyiy obraz zhizni [Healthy lifestyle]. Kyiv: Olympic Literature; 1999, 320 p. (In Russian).

31. Hawley E. T., Franks D. B. Ozdorovchyj fitnes [Health Fitness]. Kyiv: Olympic Literature; 2000, 367 p. (In Ukrainian).

32. Duboghaj 0. D., Aljoshyna A. I., Lavrynjuk V. Je. Osnovni ponjattja i terminy zdorov'jazberezhennja ta fizychnoji reabilitaciji v systemi osvity [Basic concepts and terms of healthcare and physical rehabilitation in the education system]. Lucjk: Volynsjkyj nacionaljnyj universytet imeni Lesi Ukrajinky; 2011, 296 p. (In Ukrainian).

33. Maghljovanyj A. V. Osnovy informacijnogho polja zdorov'ja osobystosti [Basics of information field of personality health]. Visnyk Chernighivsjkogho nacionaljnogho pedaghoghichnogho universytetu imeni T. Gh. Shevchenka. Serija: Pedaghoghichni nauky. Fizychne vykhovannja ta sport. 2010; 81: 285-289. (In Ukrainian).

The work was carried out according to the plan of the Ministry of Agrarian Policy and Food of Ukraine on the theme of "Theoretical and methodological bases of the optimization of the physical education system of the students of the Ukrainian higher educational institutions" (state registration number 0112U001618). 
ORCID and contributorship:

Grygoriy P. Griban - 0000-0002-9049-1485 A,E

Tetiana Ye. Yavorska - 0000-0001-6104-2202 ${ }^{A, B}$

Pavlo P. Tkachenko - 0000-0003-4407-8611 ${ }^{\mathrm{C}}$

Olga V. Kuvaldina - 0000-0002-1153-2286 ${ }^{D}$

Zoia M. Dikhtiarenko - 0000-0003-1869-7494 ${ }^{\mathrm{C}}$

Eduard A. Yeromenko - 0000-0002-8029-2247 ${ }^{D}$

Andrii M. Lytvynenko - 0000-0002-0352-9511 ${ }^{B}$

Nataliia V. Hresa - 0000-0002-0517-4822 ${ }^{F}$

Ivan M. Okhrimenko - 0000-0002-8813-5107 ${ }^{E}$

Igor S. Ovcharuk - 0000-0002-0826-7688 ${ }^{\mathrm{C}}$

Kostiantyn V. Prontenko - 0000-0002-0588-8753 ${ }^{F}$

\section{Conflict of interest:}

The Authors declare no conflict of interest.

\section{CORRESPONDING AUTHOR}

\section{Kostiantyn V. Prontenko}

Department of Physical Education, Special Physical Training and Sport, S. P. Koroliov Zhytomyr Military Institute, Zhytomyr, Ukraine tel: +380675069142

e-mail:prontenko-kostya@ukr.net

Received: 04.02 .2020

Accepted: 08.05 .2020 